\title{
Effect of interferential current in patients with fibromyalgia: a systematic review
}

Efeito da corrente interferencial em pacientes com fibromialgia: uma revisão sistemática Efecto de la corriente interferencial en pacientes con fibromialgia: una revisión sistemática Mayara Tavares da Silva', Fernanda Mendonça Araújo ${ }^{2,3}$, Mayara Ferreira Araújo4, Josimari Melo DeSantana ${ }^{5}$

\begin{abstract}
I High-intensity and widespread muscle pain is the main complaint of patients with fibromyalgia. Interferential current is a treatment often used in pain relief; however, its effects on these patients are unclear. The objective of this review was to analyze the effects of interferential current therapy on the treatment of patients with fibromyalgia in previously published scientific articles. We searched the following databases: Central, CINAHL, Lilacs, PEDro, Medline (PubMed), SciELO, Science Direct, Scopus and Web of Science on November 2016. We included only controlled clinical trials and had no restrictions for language and date of publication. We used the Cochrane Collaboration's tool to assess the risk of bias of the articles. We found a total of 415 articles, however, only four of them were selected for analysis. Three of these studies were excluded because they were not controlled clinical trials. Thus, only one study was analyzed for this review. According to the study the combination of ultrasound and interferential current improved pain relief and the sleep quality of patients with fibromyalgia. However, the study presented a high risk of bias, being impossible to verify the isolated effect of the interferential current in those patients. Randomized controlled studies on the use of interferential current in patients with fibromyalgia are lacking on literature. The results of this review evidence the importance of developing future studies with adequate
\end{abstract}

methodological design and using only interferential current therapy to improve the use of this therapy for these patients in this clinical setting.

Keywords I Fibromyalgia; Electric Stimulation Therapy; Review.

RESUMO I A dor muscular generalizada de alta intensidade é a principal queixa de pacientes com fibromialgia. A corrente interferencial é um tratamento frequentemente utilizado no alívio da dor, porém, seus efeitos nesses pacientes não estão claros ainda. Assim, esta revisão objetivou analisar os efeitos da corrente interferencial no tratamento de pacientes com fibromialgia em artigos científicos previamente publicados. As bases de dados Central, CINAHL, Lilacs, PEDro, Medline (PubMed), SciELO, Science Direct, Scopus e Web of Science foram pesquisadas em novembro de 2016. Somente ensaios clínicos controlados, sem restrições de idioma e período de publicação foram incluídos. A ferramenta da Colaboração Cochrane foi utilizada para avaliar o risco de viés dos artigos. Dessa forma, um total de 415 artigos foram encontrados e apenas quatro deles foram selecionados para análise. Três artigos foram excluídos por não serem ensaios clínicos controlados. Assim, apenas um artigo foi analisado para esta revisão. Neste estudo, a combinação do ultrassom com a corrente interferencial melhorou a dor e a qualidade do sono de pacientes com fibromialgia. No entanto, apresentou-se

Study performed on the Department of Physical Therapy, Center for Biological and Health Sciences of the Universidade Federal de Sergipe (UFS) - São Cristóvão (SE), Brazil.

'Undergraduate degree in Physical Therapy and master's student in Health Sciences from the Universidade Federal de Sergipe (UFS) São Cristóvão (SE), Brazil.

${ }^{2}$ Substitute professor of the Department of Physical Therapy of the Universidade Federal de Sergipe (UFS) - São Cristóvão (SE), Brazil. 3Master's degree and PhD student in Physiological Sciences from the Universidade Federal de Sergipe (UFS) - São Cristóvão (SE), Brazil.

${ }^{4}$ Physical therapist and undergraduate degree from the Universidade Federal de Sergipe (UFS) - São Cristóvão (SE), Brazil. ${ }^{5} \mathrm{PhD}$ in Rehabilitation Sciences. Professor of the Department of Physical Therapy from the Universidade Federal de Sergipe (UFS) São Cristóvão (SE), Brazil. 
alto risco de viés e não foi possível verificar o efeito isolado da corrente interferencial nesses pacientes. Existe uma grande carência de estudos controlados, com distribuição aleatória, sobre o uso de corrente interferencial em pacientes com fibromialgia. Os resultados desta revisão evidenciam a importância do desenvolvimento de estudos futuros, com desenho metodológico adequado e terapia independente com corrente interferencial, a fim de melhorar a indicação da corrente para esses pacientes na prática clínica.

Descritores | Fibromialgia; Terapia por Estimulação Elétrica; Revisão.

RESUMEN | El dolor muscular generalizado de alta intensidad es la principal reclamación de pacientes con fibromialgia. Un tratamiento frecuentemente empleado para aliviar este dolor es la corriente interferencial, pero sus efectos todavía no son conocidos. Teniendo en consideración este hecho, el propósito de esta investigación es comprobar los efectos de la corriente interferencial en el tratamiento de los pacientes con fibromialgia publicados en los artículos de investigación. Se buscaron estos trabajos en las bases de datos Central, CINAHL, Lilacs, PEDro, Medline (PubMed), SciELO, Science Direct, Scopus y Web of Science en noviembre de 2016. Se incluyeron solamente ensayos controlados, sin restricción de idiomas o periodos de publicación. Se utilizó la herramienta Colaboración Cochrane para evaluar el riesgo del sesgo de los trabajos. De esta manera, fueron encontrados 415 trabajos, de estos, solamente cuatro fueron seleccionados para análisis. Se excluyeron tres trabajos porque no eran ensayos controlados, siendo analizado solamente uno en la investigación. En este trabajo analizado, los tratamientos con ultrasonido y con corriente interferencial ayudaron a mejorar el dolor y la calidad del sueño de los pacientes con fibromialgia, sin embargo, el trabajo presentó alto riesgo de sesgo, no siendo posible comprobar solamente el efecto de la corriente interferencial en estos pacientes. Hay muy pocos estudios controlados aleatorizados sobre el empleo de la corriente interferencial en pacientes con fibromialgia. Los resultados de esta revisión demuestran la importancia de desarrollar futuras investigaciones con marco metodológico adecuado y terapia independiente con corriente interferencial a fin de mejorar la indicación de este tratamiento para pacientes con fibromialgia en la práctica clínica.

Palabras clave | Fibromialgia; Terapia por Estimulación Eléctrica; Revisión.

\section{INTRODUCION}

Fibromyalgia is a chronic disease of undefined origin; however, symptoms such as prickling sensation, numbness and thermal sensitivity on the painful area can suggest that this disease may have a neuropathic etiology ${ }^{1}$. This disease mostly affects women and the prevalence of risk is between 40 and 60 years old ${ }^{2}$. The main complaint is high-intensity and widespread muscle pain, however, there are other clinical manifestations, such as stiffness, paresthesia of the extremities, subjective feeling of edema, fatigue, sleep disorders and depression. These symptoms directly affect the psychological and cognitive functions of the person ${ }^{3-5}$.

One of the usual methods to accurately diagnose this disease is The American College of Rheumatology (ACR) 1990 criteria, which presents frequent characteristics such as referred pain and the presence of tender points on eleven of eighteen specific areas on the body described in literature and axial pain on both sides of the body for three months. However, these criteria have not been properly adapted in primary health care yet. Thus, Wolfe et al. updated this study in 2010, describing some characteristics as the most commonly present in patients with fibromyalgia, such as fatigue, depression and anxiety, which facilitates the early and more precise diagionis ${ }^{6}$. These symptoms can cause huge impacts on the quality of life of patients and a multidisciplinary treatment is recommended for them ${ }^{2}$.

Several kinds of treatment are used to provide a better quality of life for patients with fibromyalgia. The main form of controlling and reducing the symptoms is the use of medications ${ }^{7}$. Physical therapy is also beneficial on these cases and some of the main techniques are cryotherapy, acupuncture, massage, hydrotherapy, electrothermal and phototherapeutic resources which provide relaxation and pain relief for the patients, while contributing to improve their psychological aspect ${ }^{8,9}$.

Interferential current is a type of electric stimulation of middle frequency, but modulated in low frequency, $50 \mathrm{~Hz}$ is the most comfortable and most accepted modulation by the patients ${ }^{10}$. Middle frequency is important to reduce the impedance caused by the skin and to reach deeper regions ${ }^{11,12}$. This current is an electrical stimulus that causes analgesia in musculoskeletal affections ${ }^{13}$. This therapy is used in different syndromes and diseases, such as urinary stress incontinence ${ }^{14}$, enuresis in children ${ }^{15}$, chronic nonspecific low back pain ${ }^{16}$, osteoarthritis ${ }^{17,18}$, psoriasis ${ }^{19}$, primary dysmenorrhea ${ }^{20}$ and during the postoperative period $^{21}$. 
On a study comparing the use of Transcutaneous Electrical Nerve Stimulation (TENS) and interferential current to reduce pain intensity of induced ischemic pain, both therapies were considered useful ${ }^{22}$. However, the use of interferential current is more comfortable for the patients, this suggests that more research should be developed to better understand its effectiveness ${ }^{22}$. Another similar study analyzed these therapies in the pressure pain threshold on pain-free subjects ${ }^{23}$. They concluded that there was an improvement on this variable after the application of both techniques, but the post-stimulation effect of the interferential current was more significant after 60 minutes ${ }^{23}$.

Given the effectiveness of interferential current in pain relief of these conditions, the objective of this study was to perform a systematic review on the effects of interferential current for the treatment of patients with fibromyalgia, since pain is the most aggravating characteristic of this disease.

\section{METHODOLOGY}

\section{Search Strategy}

The search for scientific articles on the use of interferential current in the treatment of patients with fibromyalgia was performed on the electronic databases: CENTRAL, CINAHL, LILACS, PEDro, MEDLINE (PubMed), SciELO, Science Direct, Scopus and Web of Science, on November 2016.

We used the descriptors "Interferential Current" and "Interferential Therapy". Those descriptors were used in a previous systematic review on the use of interferential current in musculoskeletal pain ${ }^{13}$ and were combined with MeSH Term "Fibromyalgia". Thus, the search strategy was: "Interferential Current" OR "Interferential Therapy" AND "Fibromyalgia". To only search for manuscripts on the CINAHL, Science Direct and Web of Science databases we used the filters "academic journals", "journal" and "article", respectively.

\section{Studies Selection}

The initial search was performed by two researchers (M.T.S and M.F.A.), not considering the title, abstract, name of the authors or journal in which it was published. They were responsible for the initial selection according to a pre-established criteria. The selection consisted only of controlled randomized clinical trials, there were no restrictions for language or publication date. We excluded studies evidencing the use of other electric current types or with characteristics different from those previously described, as well as those considered as doubles (repeated on databases or double data).

The abstracts were read if the title of the study presented a combination of the descriptors used, this would confirm the inclusion of the study in the sample. The study was automatically excluded if the title did not contain words related to the descriptors.

\section{Data Extraction and Quality Assessment}

The extraction of data regarding the sample, intervention and results of each study was performed by two researchers (M.T.S. and M.F.A.). We used the Cochrane Collaboration's tool to assess the risk of bias of the studies ${ }^{24}$. This tool is composed by seven domains: sequence generation, allocation concealment, blinding of participants and personnel, blinding of outcome assessment, incomplete outcome data, selective outcome reporting and other potential threats to validity (when the study presents problems that were not reported in previous items $)^{24}$. Each domain is judged for 'Low risk', 'High risk', or 'Unclear risk' of bias.

\section{RESULTS}

\section{Studies description}

The first search of this review found 415 articles, considering all databases by combining the descriptors. The first list of articles is shown in Figure 1.

We excluded 402 articles after reading their titles, since they presented no relation between interferential current and fibromyalgia on the title or the related terms. Book chapters, systematic reviews about interferential current or fibromyalgia, and about other themes were excluded. After this initial selection we selected 13 articles. However, these articles were published in more than one electronic database, thus, the final number of articles for analysis was four. However, only one of these studies was analyzed for this review, since three articles had no control group, thus, those articles were not controlled clinical trials ${ }^{25-27}$.

The analyzed study was published by Almeida et al. ${ }^{28}$ and compared the effect of combined therapy using 
interferential current and ultrasound in comparison to a placebo group. The authors evaluated 17 women older than 50 years, who were diagnosed with fibromyalgia. The patients were randomly distributed into two groups balanced by age, ethnic, body mass and educational characteristics. One group was composed by nine patients who received active treatment by combining interferential current and ultrasound, and other eight subjects received inactive mode of those therapies as a control group.

Twelve sessions of physical therapy were distributed in four weeks. Four of those sessions were performed during the night, the patients slept in the laboratory so sleep recordings could be made. The outcomes assessed were pain and sleep disturbances. To evaluate those variables, the following tools were used: body map (used to count painful areas), visual analogue scale (to quantify pain intensity in each quadrant of the body map), digital pressure (to count the number of tender points), dolorimeter (to assess the pressure pain threshold in tender points), the Brazilian Inventory for Sleep Disorders and polysomnography were used to analyze the sleep quality.

To detect the painful areas of each patient, the researchers used continuous ultrasound $(1 \mathrm{MHz}$ : $\left.0.5 \mathrm{~W} / \mathrm{cm}^{2}\right)$ and interferential current with frequency of $4000 \mathrm{~Hz}$ (AMF - $100 \mathrm{~Hz}$ ). After mapping, those areas were used as the spots to apply the therapy. One group was submitted to both active therapies and the parameter of the pulsed ultrasound was $1 \mathrm{MHz}$ and $2.5 \mathrm{~W} / \mathrm{cm}^{2}$ at each painful point. The parameters for electrical application were not specified. The other group was submitted to the system in an inactive mode (without electric current or ultrasound activity).

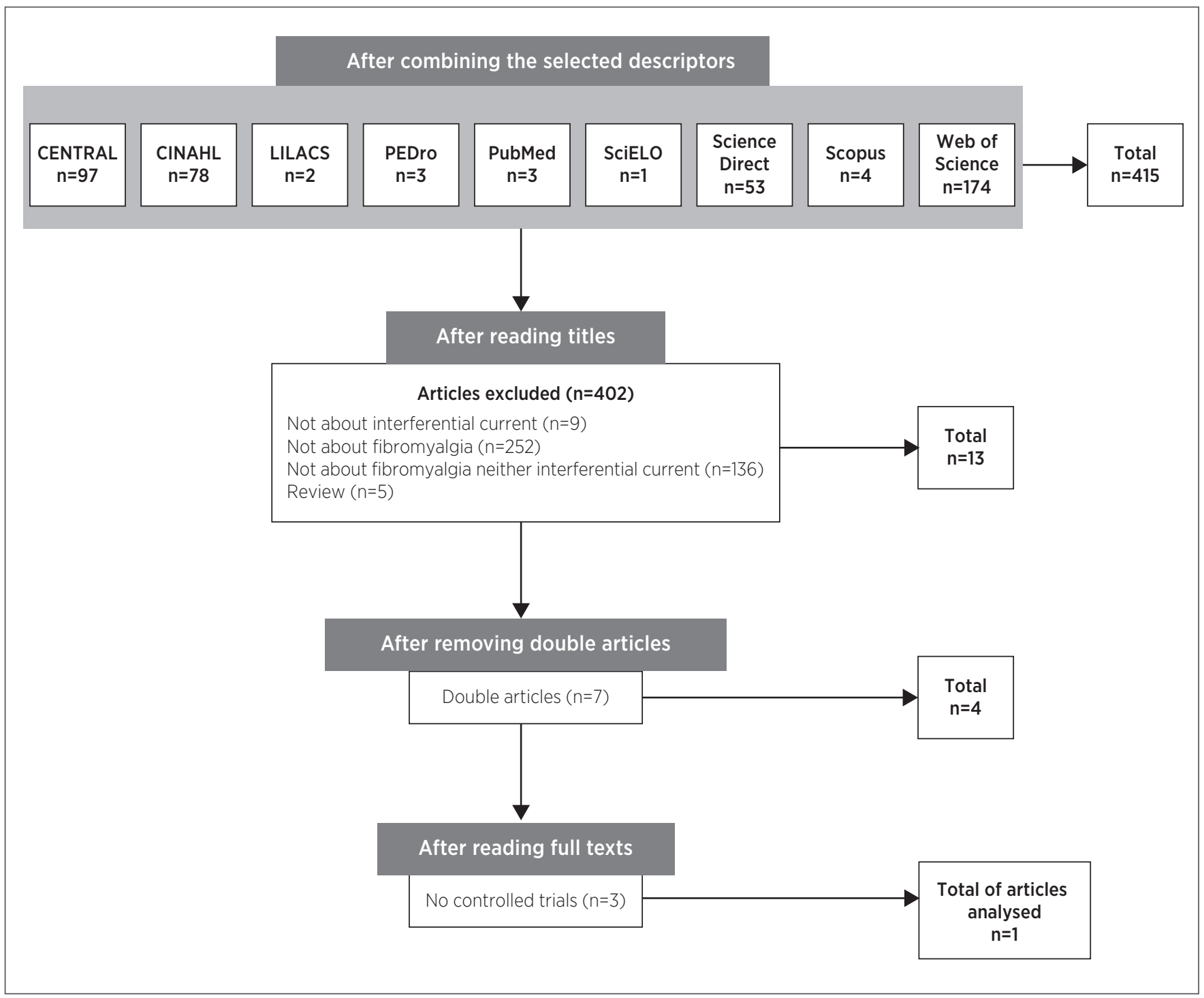

Figure 1. Flow diagram of the literature search in the databases 


\section{Treatments effects}

Only patients of the active group (that received the combined therapy) presented significant improvement in all outcomes analyzed after the treatment. The number of painful areas (by body map) and tender points in those patients was reduced. In addition, a decrease in average pain intensity scores and in pressure pain threshold values was observed in the active group, when compared to the placebo group.

The assessment of sleep by the Brazilian Inventory for Sleep Disorders improved on the "refreshing sleep" category and morning fatigue was reduced only in patients that received active therapy. Polysomnography verified a decrease on the index of arousals, in wake time after sleep onset and in the number of sleep stage changes for the patients of the active group. In addition, the authors related a decrease in sleep stage 1 percentage and sleep latency, and an increase in the number of sleep cycles only in the active group. However, there was a mistake in the representation of the table (table 3 was cited in outcomes of the Brazilian Inventory for Sleep Disorders and polysomnography, but only outcomes of sleep questionnaire were shown) and those data were not presented in the article.

\section{Risk of bias}

This study presented selection, performance, attrition and reporting biases. The study participants were separated in groups according to matching age, ethnic, body mass and educational characteristics. Thus, there was neither random sequence generation nor allocation concealment. Additionally, only the outcome assessment was blinded in this study, but not the study personnel. This study also presented incomplete outcome data and selective reporting, due to $57.5 \%$ of dropouts. The sample size was not effective and a table was missing data, the cervical points were excluded in the assessment of tender point threshold, with no explanation. Other type of bias considered is the treatment administration. In the study, the moment to apply interferential current (before, after or at the same time as the ultrasound) is not well described. The treatment application time in each session was not reported. The high risk of bias of this study is shown in Figure 2.

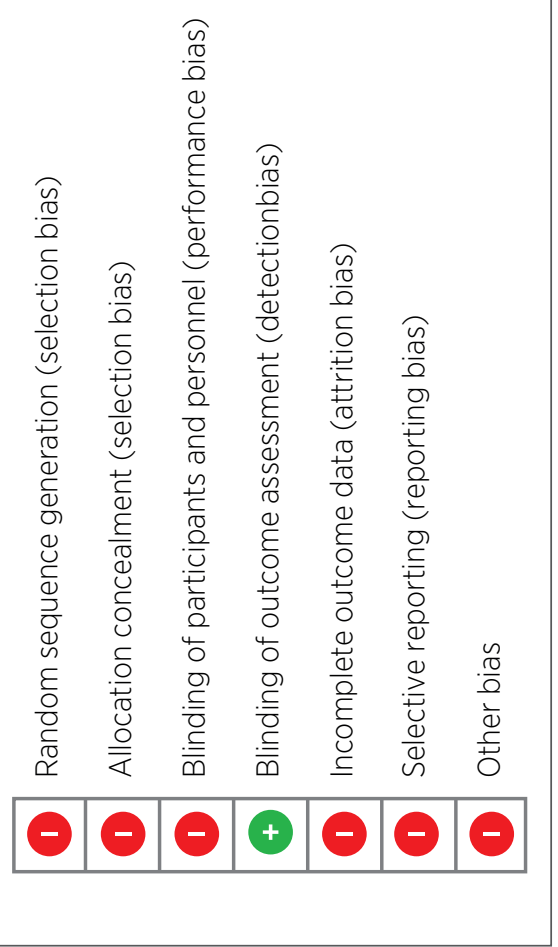

Figure 2. Risk of bias of the analyzed study

\section{DISCUSSION}

The objective of this systematic review was to verify the existence of controlled clinical trials on the use of interferential current therapy in patients with fibromyalgia and show its scientific evidences. Despite being widely used for symptomatic relief of pain in the clinical setting, there were very few studies, since only one article was included in this systematic review ${ }^{28}$.

The study we analyzed showed an association between interferential current and ultrasound effectively reducing the number of tender points and painful areas, pain intensity, morning fatigue and pressure pain threshold in tender points, it also improved the sleep quality. These data are in line with the study by Moretti et al. ${ }^{27}$, which verified that combining therapeutic ultrasound and interferential current improved pain relief and sleep quality. However, there was no difference when comparing the application of this therapy once or twice a week. This research was excluded from this review due to not being a controlled clinical trial.

Among the results found, the analyzed study did not verify the isolated effect of interferential current therapy in those patients, since it was associated to the use of ultrasound. Thus, we cannot claim that the use of 
interferential current was a determinant factor for pain relief and improvement of sleep in those patients. In addition, this study presented low methodological quality, with high risk of bias, which may interfere in the reported results. The sample size of the study seemed to be small, despite not being calculated, it showed a large loss of subjects who did not complete the protocol.

Another important methodological issue in this article is the control group. Almeida et al. (2003), considered the machines turned off as the control model, however, this method cannot produce a placebo effect. The existence of placebo results depends on how much the patient believes that he/she will get a great outcome from the treatment ${ }^{29}$. Another study on a new transient sham TENS device, which is another type of widely used electroanalgesia, the machines turned off did not blind the patients, since they did not believe that they were receiving an active treatment ${ }^{30}$. The authors proposed a stimulation of a few initial seconds (first 45 seconds in their study) and the machine was scheduled to turn off after this time ${ }^{30}$. This technique is well accepted by the scientific community, because it promotes a true placebo effect, being considered as an efficient control method for electric stimulation.

Furthermore, the allocation of subjects in the study analyzed $^{28}$ was not secret and the therapists were not blinded to perform the treatment. Thus, there is a possibility that the researcher could unintentionally interfere on the results, putting his/her expectations on them $^{31}$. Some studies show that trials with inadequate sequence generation, inadequate allocation sequence concealment, or lack of blinding cause overestimations on experimental interventions ${ }^{32-34}$. In addition, this study presented reporting bias. Two specific points for fibromyalgia (cervical points) were excluded from the analysis of the pressure pain threshold with no explanation. Furthermore, table 3 of this study was cited for two outcomes, however, only one result was shown in the table ${ }^{28}$. Thus, the treatment effects can be biased.

The assessment tools are also questionable points. Although Almeida et al. ${ }^{28}$ used some specific instruments to assess pain and sleep (the only variables of the study), the authors could have used some other gold-standard and easy to use instruments, such as the Fibromyalgia Impact Questionnaire (FIQ). FIQ is widely used to assess the impact of the disease on the life of the patients, being frequently used in scientific literature to characterize the samples of studies ${ }^{35-38}$. This questionnaire could be used as an instrument to verify the effects of the treatment on pain and other common symptoms in fibromyalgia, since this syndrome is associated with several psychosomatic changes ${ }^{6}$.

Furthermore, the authors did not present which parameters of the interferential current therapy were used, such as the time duration of the application, as well as number, size and disposition of the electrodes. In addition, body areas for the application of interferential current and ultrasound were not clearly described. Those areas were different in each patient, according to a previous diagnosis of painful areas performed in each patient, those areas were not reported in the research. Considering this information, replicating the methodological procedures is difficult, since relevant data and information were missing.

\section{CONCLUSION}

Randomized controlled studies on the use of interferential current therapy in patients with fibromyalgia are lacking in literature, since only three articles were found in six electronic databases, and only one could be analyzed. The analyzed study claimed that combining ultrasound and interferential current therapy to treat patients with fibromyalgia is advantageous for pain relief and improving sleep quality. However, more studies with adequate methodological design are needed to provide more support to the independent used of interferential current therapy in this kind of patient.

\section{REFERENCES}

1. Koroschetz J, Rehm SE, Gockel U, Brosz M, Freynhagen R, Tolle TR, et al. Fibromyalgia and neuropathic pain-differences and similarities. A comparison of 3057 patients with diabetic painful neuropathy and fibromyalgia. BMC Neurol. 2011;11:55. doi: 10.1186/1471-2377-11-55

2. Wolfe F, Brahler E, Hinz A, Hauser W. Fibromyalgia prevalence, somatic symptom reporting, and the dimensionality of polysymptomatic distress: results from a survey of the general population. Arthritis Care Res (Hoboken). 2013;65(5):777-85. doi: 10.1002/acr.21931

3. Heymann RE, Paiva Edos S, Helfenstein Jr M, Pollak DF, Martinez JE, Provenza JR, et al. Brazilian consensus on the treatment of fibromyalgia. Rev Bras Reumatol. 2010;50(1):56-66. doi: 10.1590/S0482-50042010000100006

4. Vincent A, Benzo RP, Whipple MO, McAllister S J, Erwin PJ, Saligan LN. Beyond pain in fibromyalgia: insights into the symptom of fatigue. Arthritis Res Ther. 2013;15(6):221. doi: 10.1186/ar4395

5. Moyano S, Kilstein JG, Alegre de Miguel C. New diagnostic criteria for fibromyalgia: here to stay? Reumatol Clin. 2015;11(4):210-4. doi: 10.1016/j.reuma.2014.07.008 
6. Wolfe F, Clauw DJ, Fitzcharles MA, Goldenberg DL, Katz RS, Mease $P$, et al. The American College of Rheumatology preliminary diagnostic criteria for fibromyalgia and measurement of symptom severity. Arthritis Care Res (Hoboken). 2010;62(5):60010. doi: 10.1002/acr.20140

7. Chakrabarty S, Zoorob R. Fibromyalgia. Am Fam Physician. 2007;76(2):247-54.

8. Li YH, Wang FY, Feng CQ, Yang XF, Sun YH. Massage therapy for fibromyalgia: a systematic review and meta-analysis of randomized controlled trials. PLoS One. 2014;9(2):e89304. doi: 10.1371/journal.pone.0089304

9. Letieri RV, Furtado GE, Letieri M, Goes SM, Pinheiro CJ, Veronez SO, et al. Pain, quality of life, self perception of health and depression in patients with fibromyalgia, submited to hydrokinesiotherapy. Rev Bras Reumatol. 2013;53(6):494-500. doi: 10.1016/j.rbr.2013.04.004

10. Bae Y, Lee SM. Analgesic effects of transcutaneous electrical nerve stimulation and interferential current on experimental ischemic pain models: frequencies of $50 \mathrm{hz}$ and $100 \mathrm{hz}$. J Phys Ther Sci. 2014;26(12):1945-8. doi: 10.1589/jpts.26.1945

11. Arauujo BG, Filipin KM, Pasqualli T, Ribeiro LFC, Bertolini GRF. Effect of interferential current of different amplitude-modulated frequencies, on threshold and number of accommodations on healthy painless individuals. Rev Dor. 2014;15(4):245-7. doi: 10.5935/1806-0013.20140052

12. Artioli DP, Bertolini GRF. Interferential current: application, parameters and results. Rev Soc Bras Clin Med. 2012;10(1):51-6.

13. Fuentes JP, Olivo SA, Magee DJ, Gross DP. Effectiveness of interferential current therapy in the management of musculoskeletal pain: a systematic review and meta-analysis. Phys Ther. 2010;90(9):1219-38. doi: 10.2522/ptj.20090335

14. Demirturk F, Akbayrak T, Karakaya IC, Yuksel I, Kirdi N, Demirturk $F$, et al. Interferential current versus biofeedback results in urinary stress incontinence. Swiss Med Wkly. 2008;138(21-22):317-21. doi: 2008/21/smw-12038

15. Lee HE, Park K. Efficacy of salvage interferential electrical stimulation therapy in patients with medication-refractory enuresis: a pilot study. Int Neurourol J. 2013;17(3):139-44. doi: 10.5213/inj.2013.17.3.139

16. Correa JB, Costa LOP, Oliveira NTB, Sluka KA, Liebano RE. Effects of the carrier frequency of interferential current on pain modulation in patients with chronic nonspecific low back pain: a protocol of a randomised controlled trial. BMC Musculoskelet Disord. 2013;14:195. doi: 10.1186/1471-2474-14-195

17. Burch FX, Tarro JN, Greenberg JJ, Carroll WJ. Evaluating the benefits of patterned stimulation in the treatment of osteoarthritis of the knee: a multi-center, randomized, single-blind, controlled study with an independent masked evaluator. Osteoarthritis Cartilage. 2008;16(8):865-72. doi: 10.1016/j.joca.2007.11.013

18. Gundog M, Atamaz F, Kanyilmaz S, Kirazli Y, Celepoglu G. Interferential current therapy in patients with knee osteoarthritis: comparison of the effectiveness of different amplitudemodulated frequencies. Am J Phys Med Rehabil. 2012;91(2):107-13. doi: 10.1097/PHM.0b013e3182328687

19. Walker UA, Uhl M, Weiner SM, Warnatz K, Lange-Nolde A, Dertinger $\mathrm{H}$, et al. Analgesic and disease modifying effects of interferential current in psoriatic arthritis. Rheumatol Int. 2006;26(10):904-7. doi: 10.1007/s00296-006-0102-y
20. Tugay N, Akbayrak T, Demirturk F, Karakaya IC, Kocaacar $O$, Tugay $U$, et al. Effectiveness of transcutaneous electrical nerve stimulation and interferential current in primary dysmenorrhea. Pain Med. 2007;8(4):295-300. doi: 10.1111/j.1526-4637.2007.00308.x

21. Jarit GJ, Mohr KJ, Waller R, Glousman RE. The effects of home interferential therapy on post-operative pain, edema, and range of motion of the knee. Clin J Sport Med. 2003;13(1):16-20.

22. Johnson MI, Tabasam G. An investigation into the analgesic effects of interferential currents and transcutaneous electrical nerve stimulation on experimentally induced ischemic pain in otherwise pain-free volunteers. Phys Ther. 2003;83(3):208-23. doi: 10.1093/ptj/83.3.208

23. Dalal VP, Sheth MS, Vyas NJ. Comparison of analgesic effect of interferential therapy and transcutaneous electrical nerve stimulation on pressure pain threshold on young healthy individuals. J Clin Exp Res. 2014;2(2):129-32. doi: 10.5455/ jcer.201425

24. Higgins JPT, Altman DG. Assessing risk of bias in included studies. In: Higgins JPT, Green S, editors. Cochrane Handbook for Systematic Reviews of Interventions. Version 5.1.0 (updated Mar 2011). Oxford: The Cochrane Collaboration; 2011.

25. Raimundo AKS, Brandão DL, Lucena KG. Comparative study of the analgesic effect between frequencies of interferential current in the fibromyalgia. Fisioter Mov. 2004;17(4):65-72.

26. Akarirmak U, Eryavuz M, Tuzun F, Rezvani T. Evaluation of efficiency of iontophoresis, interferential current and vitamin $\mathrm{E}$ in the treatment of fibromyalgia syndrome. Agri Dergisi. 1995; 7(2):32-38.

27. Moretti FA, Marcondes FB, Provenza JR, Fukuda TY, Vasconcelos RA, Roizenblatt S. Combined therapy (ultrasound and interferential current) in patients with fibromyalgia: once or twice in a week? Physiother Res Int. 2012;17(3):142-9. doi: 10.1002/pri.525

28. Almeida TF, Roizenblatt S, Benedito-Silva AA, Tufik S. The effect of combined therapy (ultrasound and interferential current) on pain and sleep in fibromyalgia. Pain. 2003;104(3):665-72. doi: 10.1016/S0304-3959(03)00139-8

29. Wigley R. When is a placebo effect not an effect? Clin Med. 2007;7(5):450-2. doi: 10.7861/clinmedicine.7-5-450

30. Rakel B, Cooper N, Adams HJ, Messer BR, Frey Law LA, Dannen DR, et al. A new transient sham TENS device allows for investigator blinding while delivering a true placebo treatment. J Pain. 2010;11(3):230-8. doi: 10.1016/j.jpain.2009.07.007

31. Clarke P, Sproston K, Thomas R. An investigation into expectation-led interviewer effects in health surveys. Soc Sci Med. 2003;56(10):2221-8. doi: 10.1016/S0277-9536(02)00238-1

32. Kjaergard LL, Villumsen J, Gluud C. Reported methodologic quality and discrepancies between large and small randomized trials in meta-analyses. Ann Intern Med. 2001;135(11):982-9. doi: 10.7326/0003-4819-135-11-200112040-00010

33. Pildal J, Hrobjartsson A, Jorgensen KJ, Hilden J, Altman DG, Gotzsche PC. Impact of allocation concealment on conclusions drawn from meta-analyses of randomized trials. Int J Epidemiol. 2007;36(4):847-57. doi: 10.1093/ije/dym087

34. Wood L, Egger M, Gluud LL, Schulz KF, Juni P, Altman DG, et al. Empirical evidence of bias in treatment effect estimates in 
controlled trials with different interventions and outcomes: meta-epidemiological study. BMJ. 2008;336(7644):601-5. doi: 10.1136/bmj.39465.451748.AD

35. Elvin A, Siosteen AK, Nilsson A, Kosek E. Decreased muscle blood flow in fibromyalgia patients during standardised muscle exercise: a contrast media enhanced colour Doppler study. Eur J Pain. 2006;10(2):137-44. doi: 10.1016/j.ejpain.2005.02.001

36. Sanudo B, Galiano D, Carrasco L, de Hoyo M, McVeigh JG. Effects of a prolonged exercise program on key health outcomes in women with fibromyalgia: a randomized controlled trial. J Rehabil Med. 2011;43(6):521-6. doi: 10.2340/16501977-0814
37. Schaefer C, Chandran A, Hufstader M, Baik R, McNett M, Goldenberg D, et al. The comparative burden of mild, moderate and severe fibromyalgia: results from a cross-sectional survey in the United States. Health Qual Life Outcomes. 2011;9:71. doi: 10.1186/1477-7525-9-71

38. Castro-Sanchez AM, Mataran-Penarrocha GA, Lopez-Rodriguez MM, Lara-Palomo IC, Arendt-Nielsen L, Fernandez-de-las-Penas C. Gender differences in pain severity, disability, depression, and widespread pressure pain sensitivity in patients with fibromyalgia syndrome without comorbid conditions. Pain Med. 2012;13(12):1639-47. doi: 10.1111/j.1526-4637.2012.01523.x 